\title{
The impact of sport education on fundamental values
}

\author{
Beatrice ABĂLAȘEI ${ }^{1}$, Radu IACOB ${ }^{2}$, Rareș PUNI ${ }^{3}$
}

\begin{abstract}
Sports values are those through which the human being attempts to develop under the rules, decisions, regulations, laws drafted by national or international organizations and accepted by each athlete.

In the physical education lesson, when one or more values are appropriated, becoming convictions, they particularly structure the student's behavior, child's behavior and constitute an authentic leader of the actions and the way they are. Athletic activity is the only way to systematically and continuously develop sporting values and the desire to compete induced in the physical education lesson where students receive a knowledge system that forms a true theory of competition - all in the spirit of friendship, knowledge and mutual respect based on human being dignity.

The aim of our approach is to educate children with universal values, Olympic values, and create a selfless, proactive, collaborative behavior that removes hierarchy.

At the basis of education in the spirit of universal values will be sports games with modified rules.

At the basis of the study, the survey method was based on a questionnaire and the analysis combined the qualitative and the quantitative interpretation.

The results of the study point to the need to educate children through the means of action specific to physical education and sport, implicit of universal ones.
\end{abstract}

Key words: values of olympism, sports, physical education.

\section{Rezumat}

Valorile sportive sunt cele prin intermediul cărora ființa umană încearcă să se dezvolte sub imperiul unor reguli, decizii, regulamente, legi elaborate de organizații naţionale sau internaţionale şi acceptate de fiecare sportiv.

În cadrul lecţiei de educaţie fizică, când una sau mai multe valori sunt însuşite, devenind convingeri, ele structurează în mod deosebit conduita elevului, a copilului şi se constituie ca un autentic conducător al acţiunilor şi al modului de a fi al acestuia. Activitatea sportivă este singura modalitate care valorifică sistematic şi continuu valorile sportive şi dorinţa de întrecere indusă în cadrul lecţiei de educaţie fizică unde elevii primesc un sistem de cunoştințe care alcătuiesc o adevărată teorie a competiţiei - totul în spiritul prieteniei, cunoaşterii și respectării reciproce bazate pe demnitatea ființei umane.

Obiectivul demersului nostru este de a înzestra copiii cu valorile universale, valorile olimpice, și crearea unui comportament altruist, proactiv, de colaborare din care să fie eliminată ierarhizarea.

S-a folosit metoda anchetei pe bază de chestionar, iar analiza a combinat interpretarea calitativă cu cea cantitativă, prin intermediul programului SPSS.

Rezultatele studiului au condus către ideea că educația fizică și sportul dețin mijloacele necesare educării copiilor în spiritul valorilor olimpice, implicit al celor universale.

Cuvinte cheie: valori olimpice, sport, educatie fizică.

\footnotetext{
1 Assoc. Prof., Alexandru Ioan Cuza University, Iasi, Romania, Faculty of Physical Education and Sport, e-mail: beatrice.abalasei@uaic.ro

${ }^{2}$ Lecturer, Alexandru Ioan Cuza University, Iasi, Romania, Faculty of Physical Education and Sport

${ }^{3}$ Lecturer, Alexandru Ioan Cuza University, Iasi, Romania, Faculty of Physical Education and Sport

${ }^{*}{ }^{\text {st }}$ Report of FAIRHAP - Fair Play and Happiness through Sports, 579709-EPP-1-2016-2-EL-SPO-SCP, Co-funded by the Erasmus+ Programme of European Union
} 


\section{Introduction}

Physical education and sports can be a platform conducive to the development of competencies, including values, which can benefit children's' personal growth. However, the promotion of developmental objectives in physical education is not an automatic process. It is highly dependent on the ability and knowledge of the sport/

physical education (P.E.) teachers and sport coaches, to effectively deliver the program.

There have been reported in the literature, studies that show how, for example, a fair play program increased fair play behaviors of the students and developed their social skills [1]. In another study investigated how P.E. teachers tried to teach social and moral skills in their pupils although they were not trained for it [2]. Teachers used different strategies and set different goals limiting thus the effectiveness of the intervention. The problem, recognized in the literature also, is the lack of formal training on how to develop social and moral skills. Thus, it is suggested that further research is needed to help develop clear guidelines for P.E. teachers to facilitate positive developmental outcomes especially in the area of teaching and increasing the transferability of values.

This deliverable presents the results of an exploratory survey in the 5 Partners' countries (Greece, Romania, Bulgaria, Latvia, and Italy) within the context of FAIRHAP project which aims to provide awareness about basic Olympic values and support sport/P.E. teaches and coaches, who teach sports to children, through innovative educational seminar approaches, in order to facilitate the transferring of values together with the joy through sports.

\section{Hypothesis}

Sports activities can educate proactive behavior by inoculating Olympic values.

\section{Objectives}

Objective 1: Explore the concepts that Physical Education (PE) Teachers, Sport teachers and Coaches adopt regarding values (values are conceptions about what is desirable and guide individuals in their attitudes and behaviours),

Objective 2: Explore how sport/P.E. teachers and coaches define, understand and facilitate the potential contribution of sports to the development of Olympic values through teaching social and moral skills to their pupils,

Objective 3: Identify the resources/training sport/P.E. teaches and coaches draw on to obtain their knowledge about promoting Olympic values, social and moral skills development,

Objective 4: Identify sport/P.E. teaches' and coaches' possible needs regarding new educational tools and approaches for the promotion of fundamental Olympic values.

\section{Methodology}

For the collection of data a questionnaire was developed and distributed at 50 physical education teachers, sport teachers and sports coaches in each country. A total of 250 questionnaires were collected and statistical analyses using SPSS statistical package were performed.

To facilitate the collection of data from different national settings, the survey was translated into 6 languages: English, Greek, Romanian, Bulgarian, Latvian and Italian.

Most of the survey participants were males (64\%), belonged to the 36 - 55 years age group, and had 510 years of teaching or coaching experience.

\section{Key findings \\ Value Orientation of sport/P.E. teachers and coaches}

There are five value orientations: disciplinary mastery, learning process, self-actualization, social responsibility, and ecological integration. Three of these, namely self-actualization, disciplinary mastery, and social responsibility seem to be most prominent in the survey sample.

Sport/P.E. teachers and coaches with a selfactualization (SA) orientation believe that the curriculum should be focused on personal development and the growth of the learner. These sport/P.E. teachers and coaches believe that knowledge and skills should be meaningful to each individual student and should be delivered in a manner that increases their self-esteem and the enjoyment of participation in learning. Physical educators with a disciplinary mastery (DM) orientation tend to focus on developing performance proficiency in sport skills and emphasize performance-related knowledge. Their 
main concern is for student competence. Finally, physical educators with the social responsibility (SR) value orientation consider physical activities and sports as vehicles to help students align their individual needs with the needs of the society. These teachers design the learning context in such a way as to promote cooperation and the taking of responsibility on the part of the learners.

Analysis of survey data revealed that P.E. teachers of the sample have different value priorities. Respondents from Greece, Romania and Italy place higher priority to SA and SR, respondents from Bulgaria (BG) place higher priority to DM and SR, and respondents from Lituania (LT) place higher priority to DM and SA. Explanation for the observed differences among countries, regarding value orientation, include social and cultural parameters.

For example, when examining, in desk research, the sport and physical education system in Greece, Romania and Italy it was noted that the state educational policy places strong emphasis on personal growth and development by nurturing the individual level of health and physical fitness (selfactualization), while in Bulgaria and Latvia more emphasis seems to be placed, in addition, to competitive sports. Such findings implied that physical educators' beliefs and values are compatible with the philosophy of the national curriculum.

\section{Teaching of Moral and Social Values}

Teachers, usually, have difficulty explaining the strategies they use for teaching values to their trainees. Trying to understanding how sport/P.E. teachers and coaches attempt to teach values and develop their ability to make moral judgements, in regular PE and coaching classes, respondents were asked to select from a list those methods they use.

The methods indicated as most popular by the sample were: teaching children to help each other and encouraging them to reflect on their behavior. Children of primary school age are characterized by egocentricity and for this reason, methods usually proposed by the literature include simulations, role plays, etc. to help them see the others' point of view. Respondents also seem to acknowledge that their own behavior plays a role to the social and moral development of the children and they try to model appropriate behavior and so as to "set a good example' and "create a pedagogical climate".

\section{Moral and Social Values that sport/P.E. teachers and coaches Emphasize}

The contribution of sports and physical education to the moral and social development of children is widely acknowledged. The outcomes of sports and P.E. can be understood in terms of children development in 5 domains: physical, lifestyle, affective, social cognitive. Literature review stresses also the fact that some of the benefits do not result only from participation, but of the interactions between pupils, teachers, and parents, [3]. In other words, contexts that emphasize positive experience and are managed by teachers and coaches trained for this purpose and have the support of informed parents are essential.

Sample responses regarding which values they consider important in teaching were analyzed using factor analysis. From this procedure, 3 composite factors emerged. The first factor focus on parameters that characterize sports such as determination, persistence and molding of character and includes the following values:

- Doing the best they can,

- Respecting others,

- Overcoming adversity,

- Dealing with winning and losing.

The second factor focus on teamwork and cooperation and includes the following variables:

- Discipline and hard work,

- Helping each other,

- Working together.

The third factor focus on the self and internal processes leading to self-development and includes the following variables:

- Openness to people of various ethnic or racial backgrounds,

- Respecting the rules,

- Building self-esteem.

Taken all the factors together, they exhibit a rather holistic approach towards values, from or, through, sports achievement to personal development, social interaction and teamwork.

\section{Equal Participation}

Participation in physical education has been associated not only with positive effects but also 
with negative effects such as discrimination, aggression, racism, etc. The European Union Agency for Fundamental Rights \& Council of Europe, states that "there shall be no discrimination on any ground such as sex, race, color, language, religion, political or other opinion, national or social origin, association with a national minority, property, birth, or other status' [4]. However, phenomena such as those described above are still around. The majority of the respondents ( $49 \%$ to $57 \%$ ) reported that they have encountered and/or witnessed and/or experienced the following:

-Lack of respect for the rules of sport (i.e. cheating).

-Unequal treatment of girls/women in sports compared to their male counterparts.

-Violence (i.e. fights/brawls) inside or outside the rules of sport. Includes spectator/children/parental/official/or coach violence.

-Inappropriate verbal communication (calling someone names), teasing with offensive and degrading comments, telling jokes against someone, shouting, belittling, acts of humiliation, use of trash talk, obscene gestures, or profanity between teammates or opponents.

-Physical abuse, shoving, striking, slapping, punching, beating, kicking, biting between teammates or opponents.

An interesting finding is that sport/P.E. teachers and coaches indicate lack of formal training (only $36,6 \%$ have reported training) on equal participation issues and the majority of them consider further education on the issues beneficial $(55,5 \%)$.

\section{Sport/P.E. teachers' and coaches' Training in Social and Moral Values}

Teachers used different strategies and set different goals limiting thus the effectiveness of the intervention. The problem, recognized in the literature also, is the lack of formal training on how to develop social and moral skills. Thus, it is suggested that further research is needed to help develop clear guidelines for P.E. teachers to facilitate positive developmental outcomes especially in the area of teaching and increasing the transferability of values.

Sample participants when asked to rate on a 5-point scale ranging from "strongly disagree to strongly agree" whether information on ethical issues in sport is adequately included in existing sport/P.E. teachers' and coaches' education training gave a mean score of 3,63 indicating moderate agreement. Only respondents from Bulgaria express certainty that such information is included in their training (mean 4,62) and that they have been sufficiently trained in didactics of social and moral development (mean 4,70). However, when asked whether they had received training regarding equal participation issues only half answered positively. An interesting finding is that in the issues they reported the highest percentages of formal training, such as lack of respect for the rules of sport, unequal treatment of girls/women in sports, unequal treatment of participants within the context of sporting activities due to race, religion, culture, socioeconomic status etc. they also reported highest percentages on the need for further education because these were also the most problematic issues regarding occurrence.

Regarding sources of sport/P.E. teachers and coaches education on ethical issues and values in sports with the exception of respondents from Romania and Latvia, that they state as their primary source of education the University education $(60 \%$ and $80 \%$ respectively), the rest of the sample indicate as most prominent sources books (62\%), workshops $(58,4 \%)$ and the internet $(51,2 \%)$. University education among these respondents ranks fourth with $48,40 \%$. However, regarding whether supplementary education on how to teach values in sports should be mandated for coaches the majority of the sample "strongly agrees" (mean 4.43 on a 5-point scale) with Italian and Bulgarian respondents being even more supportive of this position ( 4.72 and 4.71 respectively).

Another interesting finding here is that most respondents state that they have acquired their own values from either their families (Greeks, Italians) or from personal experience (Romanians, Latvians and Italians). Only Bulgarians report as primary sources of values their sports clubs and coaches, while "family" is in the second position. Bulgarians emphasize also the importance of the community and the culture in the acquisition of values, while they believe that personal experience is least important. These findings suggest that sport/P.E. teachers' and coaches' personal understandings, ideas and memories influence their value 
acquisition. Therefore, the way sport/P.E. teachers and coaches actively work to contribute to the social and moral development of children could reflect a globalized socialization of sport/P.E. teachers and coaches into and through sport (i.e. teaching, coaching, mentoring they have received) accompanied by differences rooted in how they as individuals make sense of their upbringing.

\section{The role of sport/P.E. teachers and coaches}

The vast majority of the teachers and coaches in this study seem to place more emphasis on the pedagogical aspects of their role as it is evident in their responses in different questions: on what children expect from a coach, the importance attributed to fair play among the Olympic values, the selection of specific values that they try to teach which point towards a holistic development of children, and the high mean scores $(4,2$ to 4,7 on a 5 -point scale) that they attribute to the contribution of sports in transmitting social and moral values implying their involvement to it. In particular, analyzing their answers regarding children's expectations on their role, sport/P.E. teachers and coaches seem to emphasize their role as helping children attain their dreams through encouragement $(76 \%)$ and inspiring them by setting a good example (70\%), while skill improvement ranks third $(51,6 \%)$. And this despite the fact that the majority of the respondents are males (64\%) and have less than 10 years' of experience. Studies have shown that more male than female teachers perceive themselves as subject matter experts, while most female teachers see themselves as balanced group teachers combining the distinct aspects of expertise.

In addition, literature findings suggest that new teachers perceive their professional identity at the beginning of their career in a more differentiated way than their older colleagues placing more emphasis on the subject matter [6]. The results of this study point towards a more combined approach especially since P.E. teachers more than the other specialties teachers are not so much in a "knowing" environment as in a "doing" environment, [5]. Furthermore, there is some research evidence that many teachers "find the pedagogical side of their profession more important than the didactical side and the subject matter side [6]. There is also research evidence that this part of teaching enhances the quality of students' learning processes.

\section{Boys and Girls Participation in Sports}

According to the number and gender of the children participants have reported that they train, the analogy is $58 \%$ boys vs $42 \%$ girls showing a masculine superiority in participation. Similar trends have been observed in many studies attributing it to the orientation and content of the P.E. curriculum that seems to favor boys' participation and learning more than that of the girls. Although there are researchers and practitioners that suggest separation of boys and girls in physical education class so as to increase girls' participation this could involve the loss of some educational outcomes that the co-existence of the genders entail.

\section{Recommendations}

Teachers and coaches should be aware of their value orientations as these are involved and affect their interaction and relationship with students and influence their decisions about teaching objectives, implementation of the content, and the evaluation procedures. Designing of training procedures and materials should take into consideration teachers' value orientations, since understanding teachers' and coaches' belief systems is an essential element for reducing the filtering of new knowledge.

A common denominator to all studies regarding moral development in children is that moral growth is not an automatic consequence of participation in physical activity, but it requires systematic and organized design and delivery to be effective.

To realize the full potential of physical education in moral and social development of children, emphasis should be given to the development of a favourable context with the cooperation of all agents: trained sport/P.E. teachers and coaches as well as supportive parents.

Sport/P.E. teachers and coaches should be supported to recognize, prevent, and deal with discrimination and the various forms that it can take.

Development of clear guidelines for sport/P.E. teachers and coaches to facilitate positive developmental outcomes through PES, particularly 
in the area of teaching and enhancing the transferability of values.

The new methods that will be developed should support pedagogical aspects and not only the subject matter or didactics, especially since the pedagogical aspect in teachers' and coaches' profession enhances the quality of children's learning processes.

A more critical appraisal of the sport and physical education curriculum could better support the achievement of the educational goals for both boys and girls.

\section{References:}

1. Vidoni C., Ward P. (2009). Effects of Fair Play Instruction on student social skills during a middle school Sport Education unit, Physical Education and Sport Pedagogy, Volume 14, Number 3, pp. 285-310(26), Publisher: Routledge, part of the Taylor \& Francis Group.

2. Jacobs J. et all (2013). Direct recordings of grid-like neuronal activity in human spatial navigation, Nat Neuroscience, Vol.16, Issue 9, pp. 188-1190.

3. Bailey R. (2006). Physical Education and Sport in Schools: A Review of Benefits and Outcomes, Journal of School Health, VL.76, Issue 8, Publisher: Blackwell Publishing Inc., pp. 1746-1561.

4. FRA - European Union Agency for Fundamental Rights (2010). Racism, ethnic discrimination and exclusion of grants ties in sport: A comparative overview of the situation in the European Union. Luxembourg: Publications Office of the European Union, p. 89.

5. Clandinin D. J. (1986). Classroom practice: Teacher images in action. London. The Falmer Press.

6. Beijaard D., de Vries Y. (1997). Building expertise: A process perspective on the development or change of teachers' beliefs, European Journal of Teacher Education, 20 (3), 243-55. 